\title{
Substantiation of Influence on Regional Integration Processes of Socio-Economic Development (Based on the Republic of Tatarstan Example )
}

\author{
Vakhitova T.M.
}

\author{
Associate Professor of the Department of general economic disciplines, \\ Kazan (Volga region) federal university (Kazan) \\ Ph.D. in economics
}

Gadelshina L.A.

Teaching assistant of the Department of general economic disciplines, Kazan (Volga region) federal university (Kazan)

Grigorieva L.L.

Teaching assistant of the English Language Department, Kazan (Volga region) federal university (Kazan)

\section{Doi:10.5901/mjss.2014.v5n18p101}

\begin{abstract}
In this paper examines the impact of the integration processes in quantitative and qualitative changes in the functioning of the socio-economic systems and developing a conceptual approach to assessing the impact of regional integration processes in the socio-economic development. Consider interaction between globalization and economic integration processes and interregion interrelations on the basis of individual RF regions study (the Republic of Tatarstan) aimed at enhancement of external economic potential use, investment attractiveness, and innovative development.
\end{abstract}

Keywords: liberalization, external economic relations, globalization of world economy, external trade turnover,investment return.

\section{Introduction}

Economic integration appears to be one of the factors of regional economic community development since core reason for integrational processes lies in economically and historically dependent need for establishment of prolonged economic relations between elements of social and economic systems in regions. This fact is caused by uneven distribution of key factors of production and generally the system of international labor division. Integrational processes allow to join efforts in order to solve problems of regional economic sectors production development in one or several countries.

Basic tendencies of research works on regional economic integration are devoted to either evolution and relationship between processes of regional integration on larger territory of Eurasia [1, 5-7], correlation between regional integration and globalization [2], or external economic cooperation of one state's regions with those of other states. Cooperation between regional economic integration and external economic relations urges to ensure achievement of synergetic effect in innovative development of regions.

Modern stage in the development of world economy with predominance of economic processes globalization is characterized by considerable changes in the structure and directions of economic relations. Despite the fact that external trade, influenced by innovations and use of global information systems, continues to rise faster than world GDP, economic relations become more intense and pass to new technological level which is a basis for international industrial cooperation.

Foreign direct investment (FDI) demonstrates particularly rapid increase and this fact is linked with advanced growth of foreign investment which will control not only the third part but a half of production of goods. Transnationalization of world economy, increase of international labor division, multiple increase of scale, dynamics and role of external trade and international economic relations are all signals of modern economic globalization occurrence [3].

Globalization as an objective tendency of human civilization development brings additional opportunities and 
promises high incomes to individual countries. Nonetheless, the level of positive or negative effect of economic globalization on national production in many cases depends on participation of the state in international labor division, degree of integration into world economy. According to P.H. Lindert [3], establishment of trade relations is generally profitable for both sides, although profits between countries are distributed unevenly. The country which changes trading conditions in higher degree gets more, and liberalization of trade may lead to losses for the nation as a whole. At the same time the role and content of globalization suppose enhancement of competition for all types of resources and therefore make it necessary to mobilize all types of national economic resources (material and managing), demand use of entire state's potential and in the first place in the areas where the country has competing advances. Along with this fact under conditions of liberalization of international trade and external economic relations from the side of the state, new economic territories - regions of different countries in the world becoming full rights participants of international labor division - are included in external economic activities.

Thus, achievement of stable economic growth of the state in higher degree depends on solution of many problems existing in regions. Practice of innovative development and industrial cooperation of developed countries proves that regional economy will stay at the edge of world economy if it does not rely on science, develop production and realization of science based industrial goods and technologies. This is also proved by American economist M.Porter who says that «competiveness is defined by special knowledge, skills and level of innovations brought into life by qualified labor force and organizational mechanisms. Processes of the creation of qualified labor force along with some of the most important influences upon innovation paces are of local origin. Paradoxically but more open global competiveness increases importance of local base». [4. 9].

\section{Analysis}

Along with other countries Russia searches for its own position and role in the process of globalization taking into account its relative advantages: wealthy basis of natural resources, scientific, technical and human potentials. External factor effect from participation of the country in exchange of goods, services, capital, labor force, and information worldwide has played a highly remarkable role in the development of domestic economy during the whole period of existence of Russia. Indices of export and import quotas measured by ratio of export and import to GDP in Russia is slightly higher than world rates.

However, low competiveness of domestic economy, practically single-crop fuel and raw materials Russian export, too excessively high concentration of Russian export to Europe under conditions of European economic growth slowing down lead to the fact that external economic relations may lose a role of one of the key factors for economic growth or, vise versa, cause economic digression. This was proved by economic crisis in 2008-2009 when Russian economy demonstrated the highest rate of collapse compared to other countries from group BRICh (Fig.1). Overcoming of these negative results, acceleration of Russian economy modernization process, its next advancing development are impossible without activation of external economic activity at regional level.

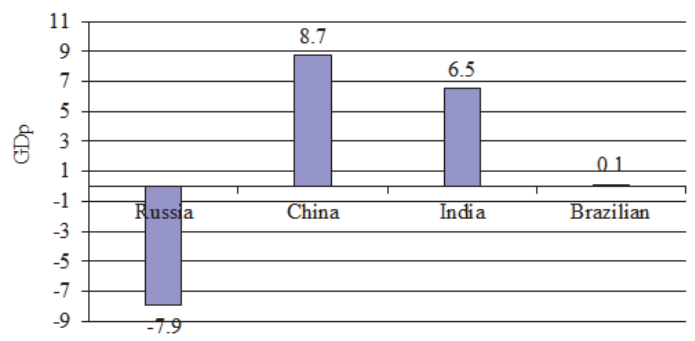

Fig.1. Increase (decrease) rate of GDP in BRICh countries in 2009 (in \% compared to analogical period of previousyear)

In Post-Soviet period with the help of profound market reforms all Russian regions received direct access to external market and opportunities to develop external economic relations independently. Basic forms of these relations - external trade and investment cooperation - became the most important factors for economic development of the state and its regions. Results of external trade activities assisted in Russian regions and the country's as a whole economic growth, development of industrial forces, inner production proportions improvement. Therefore, external trade plays an important role not only in final product realization but in its reproduction, increase of competiveness. 
Russian regions are differently involved in economic relations. Their involvement depends on their transport and geographical position, state of natural resources potential, historical development of economy and many other factors. The Republic of Tatarstan as one of the most dynamically developing regions of Russian Federation stands out of other federal units in Russia by existence of all these factors promoting deep involvement in economic relations. Taking this fact into account Tatarstan involvement in foreign trade is slightly higher than in other regions. The Republic of Tatarstan is one of the active participants in external economic activities among regions of Russian Federation.

In 2012 external trade turnover in RT was 25,2 billions of US dollars, that is $0.5 \%$ lower than in 2011 . At the same time amount of export in the Republic was equal 21.4 billions of US dollars and import equaled 3.8 billions of US dollars. Positive balance of foreign trade in the Republic of Tatarstan was 17.5 billions of US dollars against 18.5 billions of US dollars in 2011. Coefficient of export covered by income was 5.6 times. According to results of 2012, in the structure of WTO in RT $84.8 \%$ belonged to export and $15.2 \%$ - to import.

138 countries were among trading partners of the Republic of Tatarstan and export trade operations were held with 119 countries, import operations - with 97 countries. Trading partners or foreign countries' share in exchange of goods with the Republic was $94.6 \%$. Leading role in export of goods belongs to foreign countries - $95.9 \%$. In import their share equals $87.1 \%$. [5, 12]

Approximately $7 \%$ of oil in Russia is produced on the territory of Tatarstan, more than $30 \%$ of lorries, $40 \%$ of synthetic rubber, $52 \%$ of polyethylene and $5 \%$ of gross agricultural goods are manufactured here. Along with this, advantageous transport and geographical position, existence of developed transport infrastructure, qualified labor force provide the Republic with additional competitive advantages that lead to participation in international and external trade relations aimed at economic and trading development, attraction of investments, exchange of information, cultural contacts strengthening and compatriot support.

Another indicator of external economic relations development is degree of inward investments. Tatarstan is among leaders in dynamics of investments yielding to «remote rivals» - Leningrad district and in the last years - Krasnodarsky krai. Stable growth and prominent amounts of investment is the Republic's one of the most important advantages. The most stable perspectives of development belong to regions which are able to attract investments. It is necessary to consider that in Russia inward investment is at maximum in regions with large supplies of oil and gas, since these fields are capital intensive. Therefore, existence of oil producing regional company leads to increase of investments in Tatarstan. And there is need to note that attractiveness of Tatarstan for foreign investors in recent years has also increased in automobile production. Thus, in present time chemical, petrochemical industries and mechanical engineering - basic structure building economic fields - become a perspective tendency for investments.

\section{Method}

To evaluate efficiency of investments we shall use return on investment index in given economic sectors in Tatarstan. Calculation of index is based on the use of data on money flows (investments) in main capital by types of economic activity and shipped goods of Tatarstan own production, work and services completed by own forces in the Republic of Tatarstan for the period from 2000 until 2011. [7] Index of investment return is defined by division of general amount of goods shipped by machine building, chemical and petrochemical industries by sum of investment into main capital in appropriate fields.

$$
x_{i}=\frac{\sum_{k=1}^{n} Q_{k}}{\sum_{k=1}^{n} I_{k}}
$$

Where Q - quantity of goods shipped; I - investments in main capital.

Data presented in the table where $x^{x}, x_{2}$ - indication of return on investments made in mechanical engineering and coefficient of return on investments in chemical and petrochemical industries of Tatarstan accordingly.

Table

Return on investments in mechanical engineering, chemical and petrochemical industries in the Republic of Tatarstan for the period of 2000-2011.

\begin{tabular}{|c|c|c|c|c|c|c|c|c|c|c|c|c|}
\hline Years & $\mathbf{2 0 0 0}$ & $\mathbf{2 0 0 1}$ & $\mathbf{2 0 0 2}$ & $\mathbf{2 0 0 3}$ & $\mathbf{2 0 0 4}$ & $\mathbf{2 0 0 5}$ & $\mathbf{2 0 0 6}$ & $\mathbf{2 0 0 7}$ & $\mathbf{2 0 0 8}$ & $\mathbf{2 0 0 9}$ & $\mathbf{2 0 1 0}$ & $\mathbf{2 0 1 1}$ \\
\hline$x_{1}$ & 34,6 & 37,7 & 26,0 & 47,3 & 51,4 & 51,8 & 24,1 & 10,3 & 17,5 & 24,2 & 42,6 & 23,5 \\
\hline$x_{2}$ & 7,5 & 7,2 & 10,3 & 8,1 & 6,6 & 6,1 & 5,0 & 4,9 & 4,1 & 2,6 & 3,3 & 6,2 \\
\hline
\end{tabular}


As it is clear from the table return on investments in mechanical engineering sector value is significantly higher than values of return on investment indices in chemical and petrochemical industries. This predominance of return on investment in mechanical engineering sector is explained by the fact that market price for this field's products is reasonably high because it is capable of competiveness and in good request in inter-regional market and $\mathrm{CIS}$. Therefore, one can note that this sector is considered to be the most perspective and economically effective in Tatarstan.

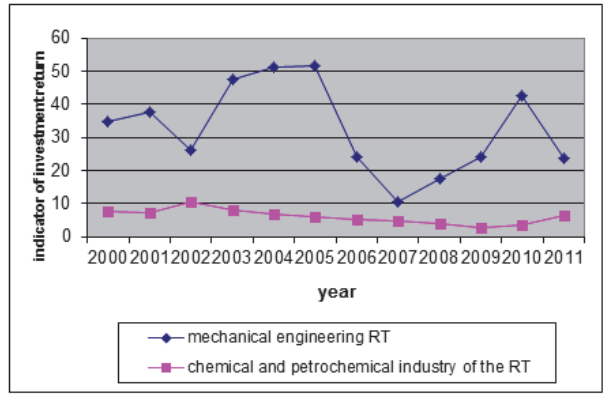

Fig.2. Dynamics of return on investment in machine engineering, chemical and petrochemical industries of the Republic of Tatarstan for the period of 2000-2011.

Nevertheless, if one looks at the structure of investments by types of economic activity [13], investment share in mechanical engineering sector equals approximately $2 \%$, whereas investment share intended for the development of petrochemical industry reaches approximately $30 \%$ yearly. This could be explained by the fact that petrochemical sector is the most attractive and capital intensive for business investments. Existence of regional oil producing company also leads to increase of investments in Tatarstan. Besides, the republic receives more considerable investments from federal budget in comparison with other regions - rivals, e.g. for realization of megaprojects (World Summer Universiade).

Dynamics of indices of return on investment in mechanical engineering, chemical and petrochemical industries in the Republic of Tatarstan for the period of 2000-2011 is presented in the picture (Fig. 2) [12].

\section{Result}

Return on investment in chemical and petrochemical industries is more stable and has positive dynamics at the end of the research. At the same time return on investment in mechanical engineering fluctuates with large amplitudes and this indicates unstable situation in this sector. From our point of view, this fact proves absence of strategic plans for the development of separate sectors and also inter-regional and external trade relations. Although given instrument (automatic planning) could solve systematic problem of the field and provide dynamic development of machine engineering (cars, equipment and transport) in long-term perspective.

It is known that attractiveness of Tatarstan automobile industry for foreign investors has increased during last years. Creation of joint enterprises with foreign car manufacturers (Kamaz and Daimler, Ford and Sollers, car components manufacturer Magna) in 2008 had a positive effect on this field. Attractiveness of foreign investments increase in Tatarstan is connected with the fast growing demand for cars, improvement of investment climate in recent years, development of transport infrastructure reducing economic distance from large sale markets in perspective.

\section{Conclusion}

Thus, taking into account sufficiently rapid increase of trade and investment flows, one can state that under conditions of economic globalization synergetic effect is reached as a result of cooperation among integral processes at different levels, under influence of globalization and socio-economic development of regions through their complementarity. It is based on multiple intersection two- and many-sided agreements with participation of federal and regional governments, subnational and supranational institutes. Inner and inter-regional economic relations are summoned to become one of the key factors in the effective development of regional socio-economic systems, overcoming of crisis phenomena in economy, its innovative growth. 


\section{References}

Vinokurov E., Libman A. Two Integration Processes in Eurasia // Voprosy Ekonomiki. No 2. 2013. P.47-67.

Bagautdinova, N.G., Murtazina, G.R., Fazlieva, E.P., Naida, A.M. Improvement of the regional management system using the labor potential index // World Applied Sciences Journal, 27(1), 2013, 107-111.

Alpatova E.S., Makarov A.N., Maksutina E.V., Nazmeev E.F. Modern labor market in Russia and its regulation. Life Science Journal 2014; 11(6s): 350-353.

Lindert P.H. International Economics. University of California at Davis. Eighth edition, 1992. P. 65.

Panasyuk, M.V., Gafurov, I.R., Novenkova, A.Z. Influence of international transport and logistics systems on economic development of the region // World Applied Sciences Journal, 27(13), 2013, 135-139.

Porter M. The Economic Performance of Region//Regional Studies.2003. Vol.37 No 6-7.

Markov, V.A., Bagautdinova, N.G., Yashin, N.S. Improvement of instruments of the state cluster-based policy in the contexts of economic entities interrelation asymmetry // World Applied Sciences Journal, 27(13), 2013, 130-134.

Nugumanova L.F., Novenkova A.Z., Abdulganiev F.S., Toropova N.V. The Role of Gender Factors in the Formation of Investment Attractiveness of the Territory/l Mediterranean Journal of Social Sciences.- Vol.5, No12, (2014)-pp.97-102.

Abendroth, A.-K., den Dulk, L. Support for the work-life balance in europe: The impact of state, workplace and family support on work-life balance satisfaction // Work, Employment and Society, 25 (2), 2011. pp. 234-256.

Gafurov I.R., Platonova O.U., Pratchenko O.V. New State Economic Policy - Cluster Policy Cluster Policy as the Factor of Innovative Development of Europe// Mediterranean Journal of Social Sciences.- Vol.5, No12, (2014)-pp.107-112.

Sarkin, A.V., Bagautdinova, N.G., Averianov, B.A. Development and implementation of adaptive science-intensive manufacture management system based on management processes automation // World Applied Sciences Journal, 27(13), 2013, 159-164.

Safiullin N.Z., Gafurov I.R., Safiullin L.N., Odintsova U.L. Modern Information Resources in Education// Mediterranean Journal of Social Sciences.- Vol.5, No12, (2014)-pp.113-116.

Clark, S.C. Work/family border theory: A new theory of work/family balance // Human Relations, 53 (6), 2000. pp. 747-770.

Bagautdinova N.G., Nayda A.M., Hayrullin B.A., Arzhantseva N. Behaviour of Households on Financial Investments Market// Mediterranean Journal of Social Sciences.- Vol.5, No12, (2014)-pp.103-106.

Gainova R.A., Shaidullin R.N., Safiullin L.N. and Maratkanova E.M. Infrastructural Component in Maintenance of Competitiveness of Region// World Applied Sciences Journal, 27(13), 2013, pp. 97-101. www.tatstat.gks.ru

Schaufeli, W.B., Bakker, A.B. Job demands, job resources, and their relationship with burnout and engagement: A multi-sample study /I Journal of Organizational Behavior, 25 (3), 2004. pp. 293-315.

Safiullin M.R., Samigullin I.G. and Safiullin L.N. Model of Management of Competitiveness of a Machine-building Complex// World Applied Sciences Journal, 27(13), 2013, pp. 212-216. 
